\title{
AN EXPLORATION OF THE INTERACTION BETWEEN BIM TECHNOLOGY AND THE BUSINESS PROCESS OF A CONSTRUCTION ORGANIZATION IN BIM IMPLEMENTATION
}

\author{
BING CHEN, ANITA M. M. LIU \& YUANYUAN HUA \\ Department of Real Estate and Construction, The University of Hong Kong, Hong Kong
}

\begin{abstract}
Building information modelling (BIM) has been considered as a possible solution to common problems in the construction industry, e.g., rework and slow delivery, and also an innovative resource providing potential competitive advantage for construction organizations. However, the adoption of BIM in a construction organization cannot always guarantee the anticipative positive value for the organization. Whether the structure of BIM technology fits the business process of a construction organization during BIM implementation plays an important role in IT-business-value creation, especially at the process level. Therefore, this research aims at exploring how the interaction between BIM technology and the business process of a construction organization can create IT business value at the process level. Based on an adaptive structuration theory, a conceptual framework is developed to fulfill the research aim. There are two parts in the conceptual framework: i) process-technology fit between the structure of BIM technology and the business process of a construction organization influences process-level IT business value through appropriation of BIM technology, and ii) a dynamic interaction cycle of appropriation of BIM technology, business process reengineering and process-technology fit. Keywords: process-technology fit, building information modelling (BIM), IT business value.
\end{abstract}

\section{INTRODUCTION}

The construction industry tends to be at a disadvantage due to the popular image of the industry: low innovation, unsafe working practices, slow delivery and cost overrun (e.g., Larsen et al. [1] and Frimpong et al. [2]). Much of this criticism can be attributed, at least in part, to the highly fragmented delivery structure that has beset the industry [3]. In recent decade, the introduction of building information modelling (BIM) becomes a possible solution to the "fragmented" problem by integrating the different project phases of design, construction and operation and coordinating various stakeholders and professionals to enhance the project performance, e.g., "time and cost savings in project delivery and improved quality of the product" [4]. For construction organizations, in the BIM wave, adopting BIM technology provides them opportunities to achieve internal improvement and thus gain a competitive advantage in the marketplace [5].

However, the adoption of advanced technology cannot always guarantee the anticipative positive business value in practices as well as in empirical research (e.g., Hitt and Brynjolfsson [6] and Ray et al. [7]). There are some reasons why researchers cannot find consistent significant positive effect of adoption of advanced technology on business value.

On one hand, since technology has surface structure of functionality and deep structure of resources and rules in its own right, whether they fit the business process influence how people appropriate the technology to conduct tasks under the business process through which value is created [8], [9]. In other words, it is the appropriation of BIM technology by people that determines the business value brings by the technology, instead of the adoption decision of BIM technology or the characteristics of the technology itself. And the appropriation of 
BIM technology is influenced by the process-technology fit between the structure of BIM technology and the business process of a construction organization [10].

Another reason that some research fail to find positive association between technology and business value is that they tend to view value as an outcome-oriented construct reflected by some economic indicators of organizational performance, such as return on assets (ROA), market returns, or market value [11]. However, later research about IT business value has challenged the outcome-oriented measurement and argue that values that technology bring about should be evaluated at the level it has the prime impact: the process level (e.g., Tallon et al. [12] and Radhakrishnan et al. [13]). At process level, IT can create business value along the business process where it provide supports, including production and operation, inbound and outbound logistics, product and service development and marketing and sales [13].

Based on this outcome-oriented value uncertainty of BIM implementation, this research aims at exploring how interaction between BIM technology and business process of a construction organization can create IT business value at process level.

\section{INTERACTION BETWEEN BUSINESS PROCESS AND TECHNOLOGY}

\subsection{Business process in construction}

A widely-acknowledged definition of process is given by Davenport [14] as follows: "a specific ordering of activities which transform inputs into outputs across time and place". Inspired by the definition of process, business process was defined as "a set of logically related activities that converts business inputs to outputs" [15], while Hinterhuber [16] further elaborate "logically related" as "integrated and coordinated" and "business outcome" as "producing products or offering services". Summarizing previous work which has given definition to "business process", Trkman [17] defines business process as "a complete, dynamically coordinated set of activities or logically related tasks that must be performed to deliver value to customers or to fulfill other strategic goals". Important elements identified in these definitions include activities, interdependence of the activities, service and product for the customers (i.e., outcome of a process) [18].

Researchers tend to classify business process based on the criteria whether the process comprises the activities in the value chain of the organization providing for the customers (see Table 1). For example, Porter and Millar [19] group business process into value-adding primary process and infrastructural support process and Davenport and Short [20] provide similar typology of operationally-orientated and management-orientated business process. Although Manganelli and Klein [15] and Sandhu and Gunasekaran [21] have further divide support/management-orientated business process into hand-off and control process or strategic process and administrative process, their rationale to distinct supporting management business process from primary operation business process remains the same.

In a project-oriented industry like construction and engineering, there are project clients and project suppliers. Project clients typically employ construction organizations (i.e., project suppliers) who offer design and/or construction services and are usually organized as projectbased organizations which "organize work around relatively discrete projects that bring particular groups of skilled staff together to work on complex, innovative tasks for a variety of clients and purposes" [22]. According to Winch [23], construction organizations are those make up the construction projects. There are two types of project-based construction organization: system integrator and specialist technology supplier [24]. This research mainly focuses on the general contractor who acts as they system integrator that provides and integrates design and/or construction services and the final building product for the client. 
Table 1: Classification of business process.

\begin{tabular}{|c|c|c|c|}
\hline Literature & Definition & Types & Description \\
\hline \multirow[t]{2}{*}{$\begin{array}{l}\text { Porter and } \\
\text { Millar [19] }\end{array}$} & \multirow{2}{*}{$\begin{array}{l}\text { Material and } \\
\text { information flow that } \\
\text { transform business } \\
\text { inputs to outputs. }\end{array}$} & Primary & $\begin{array}{l}\text { Those involved in the physical creation of the } \\
\text { product, its marketing and delivery to buyers, } \\
\text { and its support and servicing after sale }\end{array}$ \\
\hline & & Support & $\begin{array}{l}\text { Those provide the inputs and infrastructure } \\
\text { that allow the primary processes to take place }\end{array}$ \\
\hline \multirow{2}{*}{$\begin{array}{l}\text { Davenport } \\
\text { and Short } \\
{[20]}\end{array}$} & \multirow{2}{*}{$\begin{array}{l}\text { A set of logically } \\
\text { related tasks } \\
\text { performed to achieve } \\
\text { a defined business } \\
\text { outcome. }\end{array}$} & $\begin{array}{l}\text { Operationally } \\
\text { orientated }\end{array}$ & $\begin{array}{l}\text { Those involve day-to-day carrying out of the } \\
\text { organization's basic business purpose }\end{array}$ \\
\hline & & $\begin{array}{l}\text { Management } \\
\text { oriented }\end{array}$ & $\begin{array}{l}\text { Those help to control, plan, or provide } \\
\text { resources for operational process }\end{array}$ \\
\hline \multirow{3}{*}{$\begin{array}{l}\text { Manganelli } \\
\text { and Klein } \\
{[15]}\end{array}$} & \multirow{3}{*}{$\begin{array}{l}\text { A set of logically } \\
\text { related activities that } \\
\text { converts business } \\
\text { inputs to outputs. }\end{array}$} & Value-adding & Those important to the customer \\
\hline & & Hand-off & Those that flow across functional boundaries \\
\hline & & Control & $\begin{array}{l}\text { Those that control the hand-over and } \\
\text { receiving of information etc. }\end{array}$ \\
\hline \multirow{3}{*}{$\begin{array}{l}\text { Sandhu and } \\
\text { Gunasekaran } \\
{[21]}\end{array}$} & \multirow{3}{*}{$\begin{array}{l}\text { A series of tasks, } \\
\text { which consists of } \\
\text { activities to design } \\
\text { and produce a } \\
\text { product or services, } \\
\text { creating value for } \\
\text { customers. }\end{array}$} & $\begin{array}{l}\text { Strategic } \\
\text { process }\end{array}$ & $\begin{array}{l}\text { Formulating the strategy and designing the } \\
\text { organizational structure }\end{array}$ \\
\hline & & $\begin{array}{l}\text { Administrative } \\
\text { process }\end{array}$ & $\begin{array}{l}\text { Helps in the implementation and control of } \\
\text { the development of the functional processes }\end{array}$ \\
\hline & & $\begin{array}{l}\text { Functional } \\
\text { process }\end{array}$ & $\begin{array}{l}\text { Driven by the strategy, those can directly } \\
\text { create value for customers }\end{array}$ \\
\hline
\end{tabular}

For project-based construction organizations, construction projects are their core business [24]. Construction project process refers to "a series of activities of planning, realization and direction through which materials and equipment are assembled into a building" [25]. Such process of delivering a construction project from the project supplier to its client is a value generation process [26], which is the operational business process of a construction organization according to Davenport and Short's [20] classification and terminology of business process. The operational business process of a construction organization is main focus in this research. Operational business process consists of inbound logistics process (supplier relations), production and operation process, product and service development process, sales and marketing process, customer relationship process (outbound logistics) [13].

\subsection{Surface and deep structure of technology}

Operational business process needs support from various technologies to automate some tasks within the business process (e.g., robots) and to store, process, retrieve, and disseminate information (e.g., enterprise resource planning (ERP) system) [13]. According to Wand and Weber [27], technology has surface structure and deep structure.

Surface structure of technology allow users in the real-world access information, input information, and view information on screen and in hardcopy reports. The surface structure determines the usability and functionality of a technology [28]. For BIM technology, it has various functions and application scope. BIM technology is first defined as a modelling technology that are associated with producing, communicating, and analyze building information models [5]. As the development of BIM technology and the ideas behind hard technology of BIM, BIM nowadays is considered as a system or a set of systems that enables users to generate, use, integrate and reuse building information and domain knowledge through the lifecycle of a building, not just a modelling technology [29]. The functionality 
and application scope of BIM technology cover different phases along construction project life cycle. For example, in planning and design phase, BIM technology can be used for space planning and program compliance, design configuration/scenario planning, design review (3D model visualization), BIM-based energy and lighting design and analysis, quantity takeoff and cost estimation, clash detection, constructability evaluation, etc. During construction phase, BIM can be used in following area: (4D) schedule simulation, shop drawings detail design (pipeline integration and hole preparation), construction scheme optimization, key structure nodes simulation, visualized technical disclosure, safety simulation and etc. The as-built model generated in construction phase, together with cloud server technology and GIS platform can be further used in operation phase for building maintenance [5].

Deep structure of technology reflects the meaning of the real world that the information system is aimed at modelling. For instance, the schedule reporting rules and procedures embedded in a BIM-based collaboration platform which provide guidance for contractors to submit schedule reports and for engineers and clients to make comments and instructions reflect deep structure of this platform [27]. DeSanctis and Poole [8] use another term of "social structure" to convey the meaning of "deep structure". According to DeSanctis and Poole [8], the deep structure of a technology can be described in two ways: the structural features and the spirit of this feature set. Structural features are specific types of rules and offered by the technology. Spirit refers to "the general intent with regard to values and goals underlying a given set of structural features." An example of the spirit of BIM technology is to "deliver the project in the integrated and collaborative way" [30].

For an information and communication technology which supports group work, according to Zigurs and Buckland [31], it provides three kinds of supports for organizational practices, including communication support, information processing support and process structuring support. Communication support of a technology may consist of providing communication media to facilitate mutual understanding among participants (e.g., 3D models or 4D animation) or offering extra communication channel (e.g., online communication through a BIM-based platform). Information processing support means supports the generation, gathering, analysis, structuring and evaluation of information. Process structure support means the technology can help define and shape a group working process to make the group perform the task in the most effective and efficient ways possible [32]. Based on the above description of three kinds of supports and two structures of technology, we can match them as follows: communication support and information processing support are determined by surface structure of a technology since they directly define and scope the functions of a technology; while process structure support belongs to deep structure because it set the rules that users should follow, which shape group work procedure.

\subsection{Process-technology fit}

Since technology is often used to support certain operational business process, whether the technology fits the process where it supports is a critical issue. Although there is acknowledgement in research that IT will only enhance organizational performance if it matches the business processes (e.g., Karim et al. [33] and Trkman [17]), there is limited research trying to define and scope "process-technology fit". Gribbins et al. [34] define it as "the match between the characteristics of a process and the technology capability that helps execute that process". However, this definition is directly adapted from the concept of tasktechnology fit, oversimplifies the nature of both the process and the technology structure. Hong and Kim [35] use a terminology of "organizational fit" to explain the congruence 
between ERP system and needs of the business process of an organization in terms of data, user interface and process structure, which shares the same meaning as the term "processtechnology fit" in this research.

Based on the dual structure of information technology: surface structure which determines the usability and functionality of a technology [28], and deep structure which determines the rules and procedures for the users [27], Hong and Kim's [35] three dimension of "organizational fit" cover these two dimensions of structure of information technology. "Data fit" and "user interface fit" correspond to the surface structure of information technology and "process structure fit" corresponds to the deep structure of information technology.

Regarding process, every process has its information processing or communication needs/requirements in order to accomplish the objectives of the process [36]. To conduct information processing or communication to meet process needs, people tend to draw support from various information technologies which provide relevant information processing or communication functions. The fit between the functionality of technology and the process needs is one of the dimensions of process-technology fit. Besides process needs, process has its structure which can be reflected by rules or procedures [37]. Since technology has its builtin deep structure of rules and procedures, the fit between deep structure of technology and process structure is another important dimension of process-technology fit. The mapping of technology structure, process and process-technology fit is shown as Table 2.

\subsection{Business process reengineering}

When there is misfit between business process and its supporting technology, two solutions are often considered: adapting technology features to match the existing organizational settings through customization, extension, and modification of the technology or reengineering the existing business process to match the built-in process structure of the newly adopted technology [38]. The latter approach is receiving more focus for the following two reasons.

For one thing, technology adaptation is believed to have higher level of risks because its realization depends heavily on external uncontrollable resources, e.g., consulting firms or technology vendors from a resource dependence view [35]. In addition, technology adaptation slows down the implementation process, potentially introduces dangerous bugs, and make system upgrading difficult and expensive [38].

For another, existing business process of an organization may not be effective anymore in its current business environment. In that case, automation and efficient information processing in the existing business process make no sense, and business process reengineering and continuous improvement of business process is necessary and important in enhancing the business performance. The concept of Business Process Reengineering (BPR) refers to "the fundamental rethinking and radical redesign of business processes to achieve dramatic improvements in critical contemporary measures of performance, such as cost, quality, service and speed" [39]. Compared to radical business process reengineering,

Table 2: Mapping of technology structure, process and process-technology fit.

\begin{tabular}{|l|l|l|}
\hline Technology structure [27] & Process dimensions [37] & Process-technology fit [35] \\
\hline Surface structure & Process needs & Data and user interface fit \\
\hline Deep structure & Process structure & Process structure fit \\
\hline
\end{tabular}


continuous process improvement is an incremental change process that small modifications are made to the existing business process in order to perform existing tasks more effectively, which serve as a supplement to business process reengineering in successful business process management in an organization [40]. According to Alshawi [41], business process reengineering is the result from both "business-pull": business environment changes and "technology-push": new technology adoption. Organizations operate in dynamic environments in which both external and internal contextual factors evolve over time. For instance, the requirements and expectations of their customer/client has increased in terms of product and service quality and value for money. In order to adapt to the changing conditions, strategies and subsequent business process must be redesigned and improved to remain effective and profitable in dynamic environment. Meanwhile, novel structures of the newly introduced of technology provides inspirations for designing a new business process, since the deep structure of technology has its built-in rules and work procedures, to enable alignment of business process and technology through which the use of technology can support new business process implementation [40].

Construction industry has increasingly become aware there is a need for reengineering the construction delivery process, considering that the fragmented and differentiated structure of the industry has negative effects on construction project performance (e.g., Mohamed and Tucker [42] and Love and $\mathrm{Li}$ [43]). The traditional detached and linear design and construction processes is frequently cited as the "chief culprit" to constructability problems and the subsequent design change and project delay problems. An integrated design and construction process has been considered as a solution to this problem [44]. As for project suppliers, construction organizations need to reconsider and redesign their business process about how to deliver an integrated design and construction service for their clients to meets their requirements. BIM technology, as a tool amalgamating building information and facilitating collaboration [5], can align with integrated design and construction process creating value for different stakeholders in the construction industry, including construction organizations, which is the focus in this research.

\section{IT BUSINESS VALUE}

The alignment of business process redesign and adopted advanced technology is aiming at creating business value for the organization [17]. Value is belief about desirable end-state or behavior, serving as a kind of criteria for people to select and give reason for their actions and to evaluate people (including themselves), events, goods and etc. [45]. Since value is subjective, business value that created by a company is perceived and decided by its customers. Thus, business value that a company create to the market can be reflected by the amount that customers are willing to pay in order to get their products or services [19]. Consistent with this view, business value can be measured by some economic indicators of organizational performance, such as return on assets (ROA), market returns, or market value [11]. Later researchers believe the business value create by a company can be measured beyond monetary terms, e.g., customer satisfaction [46], competitive advantage [13], and etc. IT business value is often simply defined as the impacts or contribution of IT to organizational performance (e.g., Tallon et al. [12] and Zhu and Kraemer [47]). In terms of organizational performance, IT-business-value research tend to focus on outcome-oriented firm-level performance, such as profit ability improvement, competitive advantage, cost reduction, market share increases and other economic indicator of the organization [13].

Some other research argues viewing IT business value as organizational final economic outcome is oversimplify and narrow the meaning of IT business value. Therefore, Barua et al. [48] have develop a two-stage performance impact to view IT business value, 
incorporating both "first order effects on operational level variables" such as inventory turnover, as well as "higher level variables" such as market share. Shin [49] proposes that IT brings business value for a company by reducing coordination costs, thus coordination costs reduction is the process-level measures of IT business value.

Although researchers like Barua et al. [48] and Shin [49] start to think about a more comprehensive perspective to view IT business value at intermediate process level, they still focus on the numerical benefits that IT can bring for the company. Tallon et al. [12] and Tallon [50] introduce a process-oriented perspective to link IT business value and business process closely and maintain that IT can create business value in business processes, including planning and support, supplier relations, production and operations, product and service enhancement, sales and marketing, customer relations if there is strategic alignment between business strategy and IT in an organization. Radhakrishnan et al. [13] support Tallon's idea to view IT business value at business process level and further refine this perspective by removing one dimension of IT business value: planning and support. It is because based on Porter and Millar's [19] value-added core business process model, planning and support do not belong to the core business process, they are just supporting business activities providing infrastructure for value business activities.

In cases of outcome uncertainty, adopting process perspective to view IT business value has distinct advantages over commonly-used variance theories which overemphasize the outcome effect of IT according to Soh and Markus [51].

\section{APPROPRIATION OF TECHNOLOGY}

A process perspective of IT cannot ignore how IT is actually adopted and utilized by people, i.e., appropriation of technology. Appropriation is a main construct in DeSanctis and Poole's adaptive structural theory [8], [9]. Poole and DeSanctis [9] introduced the construct of "appropriation" by tracing the source back to 19th century when philosophers Hegel and Marx use this term to explain the nature of subject-object relationships. Ollman [52] summarized Hegel and Marx's idea that to appropriate an object was to use it constructively, to incorporate it into one's life, for better or worse. Adapted from this statement, appropriation of technology means the mode or manner of adopting (utilizing) and adapting technology by users or groups of users to integrate it into their life experience and work routines. In the context of Group Support System (GSS) use, Gopal et al. [53] further explain that it is the structure of technology that is appropriated by people. In other words, appropriation exactly refers to "the manner in structures are adapted by a group for its own use through a process called structuration".

According to Ollman [52], what any artefact is and what kinds of effects it will bring about depends on how it is used, on how it enters into human activity. Poole and DeSanctis [9] took the appropriation of Computerized Axial Tomography (CAT) scanner as an example. In most cases, the physicians use CAT scanner help the patients to diagnose their diseases and decide whether they need surgery since CAT scanner was invented and designed as a diagnostic tool that benefits patients. However, there are also cases that physicians utilize the CAT scanner to confuse patients and to gain their personal interests. CAT scanners are shaped as different object and therefore will have divergent impacts depending on how they are appropriated by different users or groups of users. For BIM technology, some adopters use it only as a presentation tool to show the clients the 3D shape of the building and 4D animation of the construction process without actual and meaningful building information in the model. In that case, BIM technology are appropriated deviating from what it is designed to be. The potential value of BIM technology on construction projects and construction organizations cannot be achieved. 
The analysis implicates that appropriation of technology are not automatically determined by its design intent (i.e., "spirit" of the object). Actually, people actively select how structures of the technology are used, and adoption practices are different. Here, structure means surface and deep structure of a technology as analyzed in section 2.2.

There are three dimensions of the construct of appropriation of technology: the faithfulness of the appropriation, the group's attitudes toward the technology, and the group's level of consensus on the appropriation. Faithfulness refers to the extent to which a group uses the technology in keeping with the spirit in which it is meant to be used. A faithful appropriation involves adhering to the spirit, while an ironic appropriation entails violation of the spirit. Attitudes include the level of comfort that group members feel with the use of the technology, and the degree of respect they have for it. Level of consensus refers to the extent to which group members agree on how the technology should be appropriated [9].

\section{FRAMEWORK DEVELOPMENT}

Since this research intends to explore the interaction between BIM technology and business process of a construction organization, it is important to understand the role of technology in business process. According to Davenport [14], IT has double roles in business process (see Fig. 1). For one thing, IT can act as an enabler providing opportunities for business process reengineering. For example, for some technologies with automation functions, they can help eliminate human labor in some steps within the business process and enable producing a more structured operation process. For another IT can also perform as an implementer after business process reengineering has been completed to support organizational operation process to generate positive economic outcome. At this moment, automation technologies aligning with new business process enhance the manufacturing efficiency [54].

The double roles of IT in business process proposed by Davenport [14] can be explained by adaptive structuration theory. Adaptive structuration theory argues that when an advanced technology is first introduced in an organization, the employees experience an appropriation process through which employees examine the technology structures and choose and agree upon how to use the technology and ultimately their existing working process can be adapted to include some or all of the structures of the newly adopted technology [8]. From this point of view, appropriation of technology can enable business process reengineering to achieve process improvement. Business process reengineering offers opportunities to solve misfits between business process and technology structure [38]. However, business process may not be improved and process-technology fit may not be achieved through one-off business process reengineering practice. During technology appropriation process, the working process can be adapted recurrently to achieve process-technology fit to bring IT business value along the business process.

During the implementation of new business process where newly adopted technology can provide supports, technology structure matching with new business process is expected to bring positive value for the organization. However, different from task-technology fit theory which propose that fit or alignment between task characteristics and the capabilities of a

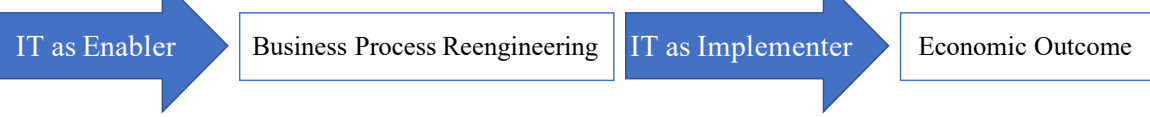

Figure 1: The role of IT in business process. (Source: adapted from Davenport [14].) 
technology can predict enhanced performance [55], adaptive structuration theory suggests that it is the choice and actual operation of the structures of technology through interaction process determine the outcomes [9]. As argued by Benbasat and Lim [56], fit between decision support systems and working process influence the way in which individuals and groups use the technology (i.e., appropriation of technology), and it is the appropriation of technology that influence performance, not the fit itself. Different organization adopt and use technology in different ways. Some may appropriate it in ways intended by the technology designers, while others may appropriate it in deviated ways. So, the use of technology brings both anticipated and unanticipated effects. According to adaptive structuration theory, in order to achieve desired enhanced performance, the appropriation of the technology should be in a stable manner. Appropriation in a stable manner means the faithfulness of and level of consensus on the appropriation should be high, and the group's attitudes toward the appropriate should be positive [53].

Taking BIM implementation in construction into consideration, BIM technology as a tool generate, integrate and store life-cycle building information across planning, design, construction, operation, and maintenance phases of a construction project, appropriation of BIM technology provide opportunities for a construction organization to redesign its traditional business process of delivering single construction service to the one allows offering integrated design and construction service, which is also the current requirement in construction industry to solve problems brought by fragmentation [57]. Only alignment of integrated design and construction process and structure built in BIM technology can leverage business value of BIM technology. Through business process reengineering and circulatory continuous process improvement, when there is fit between business process of a construction organization and the structure of BIM technology, BIM technology can be appropriated in a stable manner, namely high level of faithfulness and level of consensus on the appropriation and positive attitudes towards the appropriation. Appropriation of BIM technology in a stable manner will finally create IT business value along the business process where BIM technology can support. Accordingly, a conceptual framework depicting how interaction between business process of a construction organization and BIM technology can create process-level IT business value is established as shown in Fig. 2.

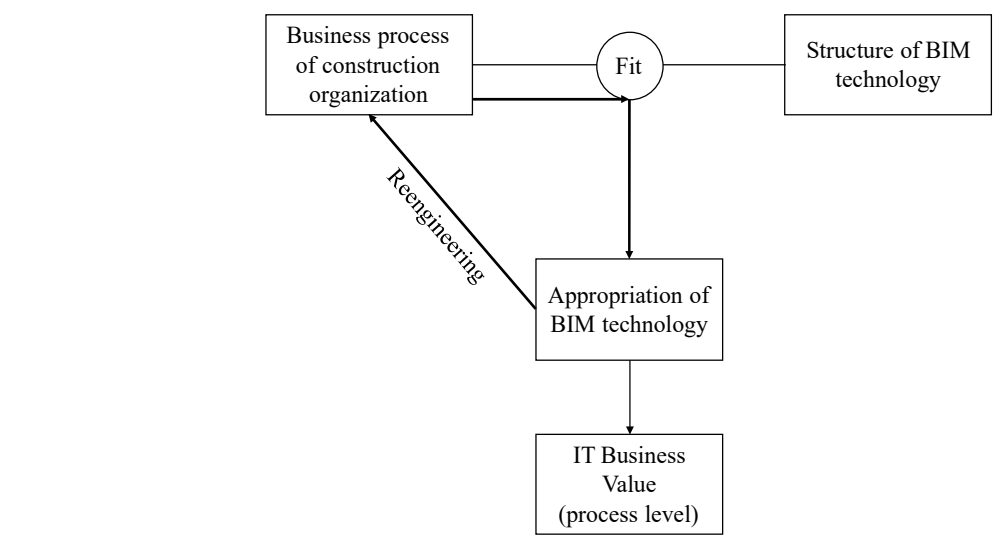

Note: $\longrightarrow$ refer to dynamic interaction of appropriation of BIM technology, business process reengineering and process-technology fit.

Figure 2: Conceptual framework. 


\section{CONCLUSION AND FUTURE WORK}

This research develops a conceptual framework to explain how BIM technology can create process-level IT business value for a construction organization through interaction between BIM technology and the business process of the organization. There are two parts in the conceptual framework: i) process-technology fit between the structure of BIM technology and the business process of a construction organization influences process-level IT business value through appropriation of BIM technology, and ii) a dynamic interaction cycle of appropriation of BIM technology, business process reengineering and process-technology fit.

The proposed conceptual framework lays foundation for further empirical studies. Conducting empirical research based on this framework offers opportunities to find out the problems of existing business process in construction organizations and how the business process can be reengineered to align with BIM technology to bring IT business value for their organizations.

\section{REFERENCES}

[1] Larsen, J.K., et al., Factors affecting schedule delay, cost overrun, and quality level in public construction projects. Journal of Management in Engineering, 32(1), p. $04015032,2015$.

[2] Frimpong, Y., Oluwoye, J. \& Crawford, L., Causes of delay and cost overruns in construction of groundwater projects in a developing countries; Ghana as a case study. International Journal of project management, 21(5), pp. 321-326, 2003.

[3] Dubois, A. \& Gadde, L.-E., The construction industry as a loosely coupled system: Implications for productivity and innovation. Construction Management \& Economics, 20(7), pp. 621-631, 2002.

[4] Kissi, J., Dainty, A. \& Liu, A., Examining middle managers' influence on innovation in construction professional services firms: A tale of three innovations. Construction Innovation, 12(1), pp. 11-28, 2012.

[5] Eastman, C., et al., BIM Handbook: A Guide to Building Information Modeling for Owners, Managers, Designers, Engineers and Contractors, John Wiley \& Sons, 2011.

[6] Hitt, L.M. \& Brynjolfsson, E., Productivity, business profitability, and consumer surplus: three different measures of information technology value. MIS Quarterly, pp. 121-142, 1996.

[7] Ray, G., Muhanna, W.A. \& Barney, J.B., Information technology and the performance of the customer service process: A resource-based analysis. MIS Quarterly, pp. 625652, 2005.

[8] DeSanctis, G. \& Poole, M.S., Capturing the complexity in advanced technology use: Adaptive structuration theory. Organization Science, 5(2), pp. 121-147, 1994.

[9] Poole, M.S. \& DeSanctis, G., Use of group decision support systems as an appropriation process. System Sciences, 1989. Vol. IV: Emerging Technologies and Applications Track, Proceedings of the Twenty-Second Annual Hawaii International Conference on, IEEE, 1989.

[10] Cooprider, J.G. \& Henderson, J.C., Technology-process fit: Perspectives on achieving prototyping effectiveness. Journal of Management Information Systems, 7(3), pp. 6787, 1990.

[11] Masli, A., et al., The business value of IT: A synthesis and framework of archival research. Journal of Information Systems, 25(2), pp. 81-116, 2011.

[12] Tallon, P.P., Kraemer, K.L. \& Gurbaxani, V., Executives' perceptions of the business value of information technology: a process-oriented approach. Journal of Management Information Systems, 16(4), pp. 145-173, 2000. 
[13] Radhakrishnan, A., Zu, X. \& Grover, V., A process-oriented perspective on differential business value creation by information technology: An empirical investigation. Omega, 36(6), pp. 1105-1125, 2008.

[14] Davenport, T.H., Process Innovation: Reengineering Work Through Information Technology, Harvard Business School Press: Boston, MA, 1993.

[15] Manganelli, R.L. \& Klein, M., The Reengineering Handbook: A Step-By-Step Guide to Business Transformation, 1994.

[16] Hinterhuber, H.H., Business Process Management: The European Approach, 1995.

[17] Trkman, P., The critical success factors of business process management. International Journal of Information Management, 30(2), pp. 125-134, 2010.

[18] Aldin, L. \& de Cesare, S., A literature review on business process modelling: new frontiers of reusability. Enterprise Information Systems, 5(3), pp. 359-383, 2011.

[19] Porter, M.E. \& Millar, V.E., How information gives you competitive advantage. Harvard Business Review, Reprint Service, 1985.

[20] Davenport, T.H. \& Short, J.E., The New Industrial Engineering: Information Technology and Business Process Redesign, 1990.

[21] Sandhu, M.A. \& Gunasekaran, A., Business process development in project-based industry: A case study. Business Process Management Journal, 10(6), pp. 673-690, 2004.

[22] Whitley, R., Project-based firms: new organizational form or variations on a theme? Industrial and Corporate Change, 15(1), pp. 77-99, 2006.

[23] Winch, G.M., The construction firm and the construction project: a transaction cost approach. Construction Management and Economics, 7(4), pp. 331-345, 1989.

[24] Winch, G.M., Three domains of project organising. International Journal of Project Management, 32(5), pp. 721-731, 2014.

[25] Albino, V. \& Berardi, U., Green buildings and organizational changes in Italian case studies. Business Strategy and the Environment, 21(6), pp. 387-400, 2012.

[26] Winch, G.M., Governing the project process: a conceptual framework. Construction Management \& Economics, 19(8), pp. 799-808, 2001.

[27] Wand, Y. \& Weber, R., On the deep structure of information systems. Information Systems Journal, 5(3), pp. 203-223, 1995.

[28] Strong, D.M. \& Volkoff, O., Understanding organization —enterprise system fit: A path to theorizing the information technology artifact. MIS Quarterly, pp. 731-756, 2010.

[29] Lin, Y.-C., Lee, H.-Y. \& Yang, I.-T., Developing as-built BIM model process management system for general contractors: a case study. Journal of Civil Engineering and Management, 22(5), pp. 608-621, 2016.

[30] Underwood, J., Handbook of Research on Building Information Modeling and Construction Informatics: Concepts and Technologies: Concepts and Technologies, IGI Global, 2009.

[31] Zigurs, I. \& Buckland, B.K., A theory of task/technology fit and group support systems effectiveness. MIS Quarterly, pp. 313-334, 1998.

[32] Dennis, A.R., Wixom, B.H. \& Vandenberg, R.J., Understanding fit and appropriation effects in group support systems via meta-analysis. Mis Quarterly, 25(2), pp. 167-193, 2001.

[33] Karim, J., Somers, T.M. \& Bhattacherjee, A., The impact of ERP implementation on business process outcomes: A factor-based study. Journal of Management Information Systems, 24(1), pp. 101-134, 2007. 
[34] Gribbins, M., Subramaniam, C. \& Shaw, M., Process-technology fit: Extending tasktechnology fit to assess enterprise information technologies. ICIS 2006 Proceedings, p. 6, 2006.

[35] Hong, K.-K. \& Kim, Y.-G., The critical success factors for ERP implementation: an organizational fit perspective. Information \& Management, 40(1), pp. 25-40, 2002.

[36] Shirani, A.I., Tafti, M.H. \& Affisco, J.F., Task and technology fit: A comparison of two technologies for synchronous and asynchronous group communication. Information \& Management, 36(3), pp. 139-150, 1999.

[37] Fjermestad, J., An integrated framework for group support systems. Journal of Organizational Computing and Electronic Commerce, 8(2), pp. 83-107, 1998.

[38] Wang, E.T., et al., Improving enterprise resource planning (ERP) fit to organizational process through knowledge transfer. International Journal of Information Management, 27(3), pp. 200-212, 2007.

[39] Hammer, M. \& Champy, J., Reengineering the Corporation: Manifesto for Business Revolution, A, Zondervan, 2009.

[40] Cooper, R., et al., Process Management in Design and Construction, John Wiley \& Sons, 2008.

[41] Alshawi, M., Rethinking IT in Construction and Engineering: Organisational Readiness, Routledge, 2007.

[42] Mohamed, S. \& Tucker, S., Options for applying BPR in the Australian construction industry. International Journal of Project Management, 14(6), pp. 379-385, 1996.

[43] Love, P.E. \& Li, H., From BPR to CPR-conceptualising re-engineering in construction. Business Process Management Journal, 4(4), pp. 291-305, 1998.

[44] Kiviniemi, A., The effects of Integrated BIM in processes and business models. Distributed Intelligence in Design, pp. 125-135, 2011.

[45] Schwartz, S.H., Universals in the content and structure of values: Theoretical advances and empirical tests in 20 countries. Advances in Experimental Social Psychology, 25, pp. 1-65, 1992.

[46] Svendsen, A.C., Boutilier, R.G. \& Abbott, R.M., Measuring the Business Value of Stakeholder Relationships Part One, 2001.

[47] Zhu, K. \& Kraemer, K.L., Post-adoption variations in usage and value of e-business by organizations: Cross-country evidence from the retail industry. Information Systems Research, 16(1), pp. 61-84, 2005.

[48] Barua, A., Kriebel, C.H. \& Mukhopadhyay, T., Information technologies and business value: An analytic and empirical investigation. Information Systems Research, 6(1), pp. 3-23, 1995.

[49] Shin, N., Does information technology improve coordination? An empirical analysis. Logistics Information Management, 12(1/2), pp. 138-144, 1999.

[50] Tallon, P.P., A process-oriented perspective on the alignment of information technology and business strategy. Journal of Management Information Systems, 24(3), pp. 227-268, 2007.

[51] Soh, C. \& Markus, M.L., How IT creates business value: a process theory synthesis. ICIS 1995 Proceedings, p. 4, 1995.

[52] Ollman, B., Alienation: Marx's conception of man in a capitalist society, Cambridge University Press, 1976.

[53] Gopal, A., Bostrom, R.P. \& Chin, W.W., Applying adaptive structuration theory to investigate the process of group support systems use. Journal of Management Information Systems, 9(3), pp. 45-69, 1992. 
[54] Attaran, M., Exploring the relationship between information technology and business process reengineering. Information \& Management, 41(5), pp. 585-596, 2004.

[55] Goodhue, D.L. \& Thompson, R.L., Task-technology fit and individual performance. MIS Quarterly, pp. 213-236, 1995.

[56] Benbasat, I. \& Lim, L.-H., The effects of group, task, context, and technology variables on the usefulness of group support systems: A meta-analysis of experimental studies. Small Group Research, 24(4), pp. 430-462, 1993.

[57] AIA, Integrated Project Delivery: A Guide - Version 1, Associated General Contractors of America, 2007. 